\title{
Politically Correct Euphemisms in Mass Media (Based on American and Turkish Online Periodicals of the Beginning of the $21{ }^{\text {st }}$ Century)
}

\author{
Oksana V. Shemshurenko ${ }^{1} \&$ Liliya Sh. Shafigullina ${ }^{1}$ \\ ${ }^{1}$ Kazan (Volga Region) Federal University, Kazan, Russia \\ Correspondence: Oksana V. Shemshurenko, Kazan (Volga Region) Federal University, 420008, Kazan, \\ Kremlyovskaya Street 18, Russia. E-mail: oksanashemshurenko@gmail.com
}

Received: June 2, 2015 Accepted: June 15, 2015 Online Published: June 29, 2015

doi:10.5539/jsd.v8n5p128 URL: http://dx.doi.org/10.5539/jsd.v8n5p128

\begin{abstract}
There is abundant research on euphemisms, but there are hardly any of them devoted to euphemisms in relation with the theory of political correctness based on the material of recognized American and Turkish online periodicals of the beginning of the $21^{\text {st }}$ century. The aim of the paper is to study the approaches to the definitions of "euphemism" and "political correctness" offered by Russian and Western linguists, to analyze the classifications and functional peculiarities of euphemisms within the framework of the theory of political correctness. The key research method is the method of comparative analysis which, based on the theoretical data about euphemisms in the English and Turkish languages, helped us to single out the cases of the use of euphemisms in modern American and Turkish online periodicals and compare the types of politically correct euphemisms in the two languages. The paper indicates the active research of euphemisms in the language of mass media by Russian and foreign (American and Turkish) linguists. The results of the study found that, compared to Turkish online newspapers and magazines, modern American online periodicals are characterized by a wider use of politically correct lexemes. The paper findings may be useful for researches who deal with political discourse, comparative analysis, the use of political lexemes and political euphemisms within the framework of the theory of political correctness.
\end{abstract}

Keywords: euphemism, political correctness, mass media, politically correct euphemisms, political discourse

\section{Introduction}

\subsection{Background}

In a constantly changing world print media, along with television, is acknowledged as the main source of information. The content of most printed publications deals with domestic social and political relations as well as foreign policy relations of leading countries. At present mass media shows "a keen interest in covering military, international and interethnic conflicts" (Kiprskaia, 2005). Newspapers and periodicals write about all the events occurring in the world and come out to be their catalyst. As a result, political vocabulary of printed editions tumbles into the modern literary language. For a good ten years print media of the majority of countries has been successfully using equivocations, misrepresentations of information and beclouding unpleasant facts in order to manipulate public consciousness. The authors of socio-political articles turn to various ways of veiling the truth and "camouflaging the reality" (Kiprskaia, 2005), replacing rude words by neutral ones, using euphemisms.

Many linguists have recognized the importance of studying euphemisms. Nevertheless, there are hardly any researches devoted to euphemisms in relation with the theory of political correctness based on the material of authoritative American and Turkish online newspapers of the beginning of the $21^{\text {st }}$ century. The aim of the paper is to study the approaches to the definitions of the concepts "euphemism" and "political correctness" offered by Russian and Western linguists, to analyze the classifications and functional peculiarities of euphemisms within the framework of the theory of political correctness.

\subsection{Status of a Problem}

Since ancient times, people have used euphemisms in the process of communication. Katsev A.M. points out that the taboo language "served as the powerful lever of word creating process" (Katsev, 1998) that led to the emergence of euphemisms.

Researchers, who deal with the language phenomenon of euphemisms (Katsev, 1998; Neaman, Silver, 1995; 
Halmari, 2010; Crespo-Fernandez, 2014; Bozkaplan, 2009; Aksan, 2012), note that the process of creation of euphemisms has experienced rises and falls depending on the moral principles that existed at different times. In the second half of the $20^{\text {th }}$ century there was one of the similar rises when the theory of "political correctness" was widely spread in the USA.

The theory of political correctness is based on the aspiration of the person to be polite, tactful and sympathetic that can be considered as the main motive for creating euphemisms. Thus, the researchers of political correctness (Adler, 1994; Gumanova, 2000; Ter-Minasova, 2000; Palazhchenko, 2004; Panin, 2004; Vildanova, 2008) assume that euphemisms are part of the language expression of political correctness.

It is necessary to stress that researches of euphemisms should be promoted in accordance with their functioning within the framework of the theory of political correctness in the language of American and Turkish print media.

\subsection{Euphemism}

It is generally accepted by most researchers that the word "euphemism" comes from the Greek euphemismos (eu - well, phzmi - I speak).

The concept of "euphemism" is closely connected with the concept of "taboo". Taboos are usually defined as prohibitions of certain actions or words that appeared in ancient times and came from mythological interpretations of the person.

In modern languages taboos have not disappeared, but are expressed in a different way. The necessity to replace taboos encouraged the emergence of euphemisms in a language.

In linguistic literature there are a great number of definitions of "euphemism". Though they do not reveal the essence of the concept in full detail, the definitions express all main functions of euphemisms. In our research we will focus on some of them which most precisely reflect the essence of euphemism as a language phenomenon.

Katsev A.M. considers euphemisms as "indirect substitutes of words naming the dreadful, shameful or offensive, leading to mitigating effect, that are brought to life by moral or religious motives" (Katsev, 1998).

According to Moskvin V.P., euphemisms are "verbal encodings used with the purpose of softening, masking, gracefully "packing" the subject of the message, however having left to any native speaker the opportunity to guess what is being spoken about" (Moskvin, 2001).

Mukhamedianova G.N. defines euphemism as "the periphrasis of the secondary name denoted by a word, a phrase or a sentence which is characterized by conscious semantic complicacy expressed in a positively high linguistic form" (Mukhamedianova, 2005). Here, the researcher pays much attention to the structural aspect of the phenomenon.

In our research we consider euphemism as the language phenomenon that is permitted by norms of verbal behaviour, socially acceptable and used for replacing forbidden, improper and incorrect words, or a taboo.

As previously mentioned, euphemisms are inextricably connected with the theory of political correctness which is described in detail and investigated in a number of works (Panin, 2004; Palazhchenko, 2004; Halmari, 2010; Crespo-Fernandez, 2014; Bozkaplan, 2009; Aksan, 2012). Euphemism can be considered as "one of the most efficient tools of creating a politically correct language" (Kiprskaia, 2005). In this regard, we will clarify what political correctness is and how the ideas of political correctness are related to euphemisms.

\subsection{Political Correctness}

In Russian the term "politicheskaia korrektnost" or "politkorrektnost" (from English political correctness, abbr. PC) has begun to be used relatively recently, however, the idea of being politically correct appeared in the USA at the end of the $20^{\text {th }}$ century. The exact time of coining the phrase "political correctness" remains obscure. Moreover, there are still debates about the interpretation of the concept itself. It is probably connected with wide applications of the term on pages of modern print media and on television.

Some researchers point at the linguistic aspect of the phenomenon, defining political correctness as "a concept-slogan firmly established in the USA, which deals with symbolic images and correction of a language code rather than with content meaning" (Komlev, 1999). Other researchers combine linguistic aspect with the social and associate "political correctness with the wide use of euphemisms that allow not to hurt the feelings of representatives of different social groups" (Leontovich, 1998; Halmari, 2010).

Thus, there are different approaches to the definition of the concept "political correctness". Though ignoring or underestimating at least one of the aspects of the phenomenon (social or linguistic), almost all researchers agree on sensitivity of the phenomenon of political correctness. According to most researchers, the aim of political 
correctness is the fight against societal discriminations.

We can say that the concept "political correctness" is versatile and multisided. Nevertheless, the researchers consider political correctness not only as a cultural and behavioural phenomenon aimed at resolving discrimination but also pay our attention to the linguistic aspect of political correctness which involves the search of new means of expression, new "language forms which have a softened or neutral character deprived of discrimination or offensive connotations" (Vildanova, 2008). Due to the ability to mitigate, euphemisms appear to be the most effective tool of neutralising negative associations.

\subsection{Research Hypothesis}

The analysis of theoretical works, devoted to the research topic, showed that Russian scientists (Ter-Minasova, 2000; Panin, 2004; Vildanova, 2008), who deal with the problems of political correctness, as well as their foreign colleagues (Neaman, Silver, 1995; Halmari, 2010; Crespo-Fernandez, 2014; Bozkaplan, 2009; Aksan, 2012), develop a hypothesis about the uniformity between politically correct terms and euphemisms. In this case we strongly support Palazhchenko's idea that "hardly any euphemisms can be taken for politically correct terms" (Palazhchenko, 2004).

The aforesaid allows us to formulate the research hypothesis as follows: politically correct terms possess the main features of euphemisms; that is, both aim at expressing a positive connotation. It is their major similarity. The difference is determined by the fact that politically correct euphemisms belong to the official style.

\section{Materials and Methods}

\subsection{Research Objectives}

The objectives of the given research are:

1) the selection and review of the theoretical literature devoted to the research topic;

2) the analysis of the classifications of euphemisms in the English and Turkish languages;

3) the comparative analysis of the typology of politically correct lexemes, which are widely used in modern American and Turkish online newspapers and journals.

\subsection{Theoretical and Empirical Methods}

To examine the hypothesis we used a variety of complementary methods. They are:

- theoretical methods including the analysis of the theoretical literature devoted to the research problem; analysis, synthesis;

- empirical methods including linguistic observation, selection, comparative analysis, component analysis.

\subsection{Body of Data}

The body of data is collected from the articles of American and Turkish periodicals published in modern American and Turkish online newspapers and magazines such as Newsweek, The Washington Post, Christian Science Monitor, The New York Times, Hürriyet, Milliyet, Yurt Gazetesi, Vatan Gazetesi.

\section{Results}

\subsection{The Classification of Politically Correct Euphemisms}

Many researchers of political discourse were concerned with the problem of the classification of politically correct euphemisms (Panin, 2004; Halanskaya, 2006; Vildanova, 2008).

Panin V.V. classifies politically correct euphemisms in relation with the types of discrimination and defines two large groups of euphemisms which he divides into subgroups. The first group includes euphemisms which directly express the ideas of political correctness used for the purpose of eliminating different types of discrimination. The second group comprises euphemisms in some or other way related to political correctness; in other words, ideological euphemisms which are used in order to avoid negative consequences in policy and economy (Panin, 2004). It should be noted the words of the second group are used rather for mitigating certain negative factors or for manipulating public consciousness. Vildanova G.A. and Palazhchenko M.Yu. consider such euphemisms "not in a way related to political correctness" (Vildanova, 2008), but call them "pseudo-politically correct" (Palazhchenko, 2004). The idea is also shared by Turkish linguists Bozkaplan Ş.A. (2009) and Aksan Y. (2012). We are not inclined to agree with this opinion, as euphemisms carry out two functions simultaneously within the framework of the theory of political correctness, that is, mitigating and masking the concept with a negative connotation. This point of view is developed in the works of Neaman J.S., Silver C.G. (1995), Halmari H. (2010), Crespo-Fernandez E. (2014). 
Since Panin V.V. considers politically correct euphemisms as "words or phrases used for mitigating the offensive or discriminatory effect, and also for concealment of the negative character of the denotatum" (Panin, 2004), it is necessary to include into the above mentioned classification the words aimed at camouflaging the negative phenomena in domestic and foreign policy relations (military conflicts, military aggression).

In our research, based on the classifications of Panin V.V. (2004), Vildanova G.A. (2008), Kiprskaia Ye.V. (2005), and also taking into account the unstable and rapidly changing global environment, we categorize politically correct euphemisms into the following three groups:

1. Euphemisms aimed at eliminating and neutralizing different types of discrimination (racial, ethnic, wealth, age). The main reasons for organising the words into this group are: 1) the aspiration not to hurt the self-respect of people who belong to ethnic minorities or the representatives of other nationalities, to emphasize their originality, equality; 2) the intention of officials to minimize the problems of wealth and social disparity; 3) the aspiration to raise the status of people of respectable age, and also to support the people who don't conform to the standards of appearance or possess physical disabilities: Jewish man in place of Jew, low-income in place of the poor, görme engelli (visually impaired) in place of kör (blind), golden-ager in place of old, toplu (overweight) instead of şişman (thick, fat), etc.

2. Euphemisms enhancing the prestige and the social status of certain professions: Garbage collector began to be called as garbologist or sanitation engineer, etc.

3. Euphemisms aimed at veiling the anti-humane policy of the state, camouflaging various forms of military aggression and criminal activity. Such euphemisms serve not so much for masking negative concepts as for presenting military operations to advantage, creating a positive image of the armed forces of the country which is involved in the conflict: device is used in place of bomb, war for peace or peacemaking operation in place of war, limited air strike or air support in place of bombing, özgürlük savaşçı1 (the fighter for independence) in place of terörist (terrorist).

3.2 The Frequency of the Use of Politically Correct Euphemisms in American and Turkish Online Periodicals at the Beginning of the $21^{\text {st }}$ Century

The analysis of the articles taken from American online periodicals of the beginning of the $21^{\text {st }}$ century (Newsweek, Christian Science Monitor, The Washington Post, The New York Times) suggests that the theory of political correctness has the greatest impact on the formation of politically correct euphemisms in the following spheres: the fight for the rights of ethnic minorities, the fight against the discrimination of mentally and physically handicapped people, expression of empathy with elderly people, various forms of military aggression, etc.

Quite often American online newspapers and magazines publish articles devoted to the issues of interethnic conflicts and racial discrimination. The analysis of lexical items in relation with the theory of political correctness indicated the frequent use of words which denote the names of various nationalities: Asian-American (a citizen or a permanent resident of the USA of Asian origin), African-American (Afro-American) (a resident of the USA with dark skin whose ancestors arrived from Africa), Hispanic (a citizen or a resident of the USA of Spanish or Latin American origin). For example, the sentence Asian-American students now make up about 45 percent of incoming freshmen, white students 30 percent, Hispanic students 9 percent and African-American only 4 percent (Newsweek, 2000) contains all the three names of the aforementioned nationalities. The component analysis of the noun Asian-American allows us to determine the semantic properties "Asian origin" and "American" in its structure. Thus, the lexeme doesn't bear any negative connotation and can be recognized as politically correct.

As for the noun African-American, we should note that some articles use the lexeme black as its synonym. For example, Atholton High School junior Tsehaitu Retta said only one or two other black students are enrolled in her advanced placement courses, even though the school is 15 percent African American (The Washington Post, 2003).

Some researchers and supporters of political correctness claim that the noun black is used in some contexts as offense. The analysis helped us find out that the noun African-American possesses the semantic components "the African origin" and "American", while the noun black implies "the representative of the black race" and "the African origin". So, the lexeme black doesn't have the semantic component "American"; in some contexts it may refer to Australian native indigenous people or black Africans. Accordingly, the meaning "American" is expressed only by the politically correct African-American.

Similarly, the semantic structure of the noun Hispanic consists of the components "Spanish-speaking" (belonging 
to the community that speaks Spanish) and "a resident of the USA". In online publications we can find the noun Latino which most researchers consider politically correct: About 47 percent of Latinos said on Census forms that they are "some other race", according to the report (The Washington Post, 2003). The component analysis showed that the main difference between Latino and Hispanic is that the noun Latino has the meanings "Latin American" and "the resident of the USA". Thus, the difference depends on one of the semantic components that makes the two lexical units distinct from each other. So, why is the word Latino considered politically correct and Hispanic politically incorrect? There is no definite answer to this question. Panin V.V. puts forward the idea that Latino "emphasizes sharing a common culture of the Latin Americans, who live in the USA, to a greater degree" (Panin, 2004) than the ethnonym Hispanic.

In the following example taken from the article published in the online newspaper Christian Science Monitor we distinguish two euphemisms: In the Brooklyn case, 24-year-old Jewish man told police he overheard a group of blackmen talking about the knockout game before he was attacked (Christian Science Monitor, 2013). Having analysed them, we may conclude both phrases are politically correct, since in the euphemisms Jewish man and blackmen the politically incorrect implications of the lexemes Jew and black are neutralized by the word man.

In the sentence Epps was the first choice of SCA cofounder Meg Palisoc, a former University of Southern California administrator who noticed that students who came from inner-city public schools were often not as academically prepared for college as their peers (Christian Science Monitor, 2013) the author of the article «Jennifer Epps inspires inner-city students and teachers in Los Angeles to excel» uses the euphemism inner-city (lit. the internal part of the city) which "appeared in the English language in the early $80 \mathrm{~s}$ of the $20^{\text {th }}$ century to mitigate negative associations related to the word ghetto" (Panin, 2004). The politically correct euphemism inner-city usually denotes densely populated old city center where mostly low income people from ethnic minorities live.

In American online periodicals of the beginning of the $21^{\text {st }}$ century there are several articles which contain politically correct euphemisms that were created in relation with the fight against the discrimination of mentally and physically handicapped people. Rock Creek, which focuses on students with learning difficulties, cut its base daily rate from $\$ 250$ to $\$ 212$ in October and to $\$ 175$ in January (The Washington Post, 2003). The article uses a less offensive euphemism students with learning difficulties in place of the phrase mentally retarded children.

In the next example the author also employs the politically correct euphemism physically challenged, thus, emphasizing polite treatment of people with physical disabilities. In 1980, Alice Weiss Doyel was diagnosed with a central nervous disorder that listed her among the thousands of physically challenged individuals in the nation (The Washington Post, 2003).

The analysis of the phrases students with learning difficulties, children with disabilities and physically challenged show that their semantic structures possess the components "mental handicap" and "physical handicap" which do not directly point to the presence of the illness and make them free from any negative connotations.

The intention to remove the discrimination of elderly citizens in the USA encouraged the American mass media to publish a number of articles that used the euphemisms senior citizen (the person who has retired) and elderly which have replaced the phrases old people and the aged previously thought to be rude and tactless.

Charles Van Vibber heartily agrees, and he claims many reasons for senior citizens to pack guns (Christian Science Monitor, 2004).

In testimony before The House Ways and Means Committee Mr. Thompson was vague about President Bush's proposal to revamp Medicare and offer drug coverage to the elderly (The New York Times, 2003).

As it has been noted, an increasing interest in covering military and interethnic conflicts as well as interference of one states with domestic policy of others in mass media led to the appearance of euphemisms aimed at masking harsh realities and creating a positive image of governments. For example, in the article "Chemical weapons: How Pentagon plans to destroy Syria's stockpile at sea" the process of the destruction of chemical weapons of Syria is veiled by politically correct expressions Syria's stockpile, chemical demilitarization business, low-risk operation that leads to the mitigation, softening of negative associations:

The Pentagon "has decades of experience in the chemical demilitarization business," the first official said, including programs underway to destroy America's own chemical weapons arsenal, as well as working with Russia and Albania to destroy chemical weapons left over from the Cold War (Christian Science Monitor, 2013).

There will also be no US troops in Syria or involved in securing port operations outside of the United States, according to the official. "We think this is a relatively low-risk operation" (Christian Science Monitor, 2013). 
The analysis of the articles taken from Turkish online periodicals of the beginning of the $21^{\text {st }}$ century (Hürriyet, Milliyet, Yurt Gazetesi, Vatan Gazetesi) let us suggest that the theory of political correctness greatly influenced the formation of politically correct euphemisms in the following spheres: the fight against the discrimination of mentally and physically handicapped people, various forms of aggression including military aggression.

Turkish online newspapers and magazines of the beginning of the $21^{\text {st }}$ century are characterized by quite frequent applications of politically correct euphemisms which were created in relation with the fight against the discrimination of mentally and physically handicapped people. For example, in the article «Engelli kıza tecavüze 18 y1l» the author uses the lexeme engelli (a person with a physical disability) instead of the words sakat or özürlü (invalid): Duruşmaya müssteki olarak katılan engelli kızın yakınları ise, sanığın en ağır şekilde cezalandirllmasinı istedi (Milliyet, 2015).

Another article headlined «Görme engelli anne, bebeğini bu gözlükle gördü» taken from the online newspaper Hürriyet in place of the lexeme kör (blind) uses the composite noun görme engelli (visually impaired) which consists of two words görme (sight) and engelli (a handicapped person), the last of which mitigates the negative connotation: Görme engelli anne, taktığ özel gözlük sayesinde dünyaya yeni getirdiği bebeğini gördü (Hürriyet, 2015).

Like American online periodicals of the beginning of the $21^{\text {st }}$ century, Turkish online newspapers and magazines often employ politically correct euphemisms camouflaging harsh realities related to various forms of aggression. For example, in place of terörist (terrorist) the Turkish press uses özgürlük savaşçısı (the fighter for independence) which possesses a more positive connotation. Besides, based on the component analysis of the phrase özgürlük savaşçısı we can assume that though the word savaşçı (a fighter, a soldier) has a negative connotation, the lexeme özgürlük (freedom, independence) mitigates the meaning, making the phrase more acceptable for use in mass media: AïHM'nin tarihinde bir ülkeye verdiği en yüksek ceza olan 2 milyon 305 bin Euro tazminata yapılan itirazın gerekçesi ise dava dosyasında Cenevre Sözleşmesi'ne yapılan atıf ve PKK'dan 'özgürlük savașçısı' olarak söz edilmesi oldu (Hürriyet, 2015). Suriye'yi yakıp ylkarken "özgürlük savașçısl" diye desteklenenler Paris'te "terörist" olmuşlardır (Yurt Gazetesi, 2015).

In addition to the aforementioned types of politically correct lexemes, Turkish online periodicals quite often employ euphemistic phraseological units. Particularly, it is connected with the frequent use of phraseological units in everyday Turkish speech. So, Professor Yüksel Ersan in his article "Siyasal İletişimde "Güzel Adlandırma" kullanımı" (2005) gives examples taken from Turkish online publications which contain phraseological euphemisms: Yakup Kepenek: CHP gemisi yüzemiyor. Genel Başkanım sizi seviyorum. Ama CHP'nin geleceğini sizden daha çok seviyorum. Sizinle olmuyor (Vatan Gazetesi, 2004). Ağzl ile kuş tutsa Baykal'a artık oy yok. CHP olağanüstü grup toplantısinda krlıçlar çekildi. Baykal'la karşı karşıya gelen 30 muhalif 'Sizinle olmuyor. Artık gidin!' dedi (Vatan Gazetesi, 2004).

\section{Discussions}

Euphemisms have been thoroughly investigated by Russian linguists Katsev A.M. (1998), Ter-Minasova S.G. (2000), Panin V.V. (2004), Vildanova G.A. (2008) and foreign researches Neaman J.S., Silver C.G. (1995), Halmari H. (2010), Crespo-Fernandez E. (2014), Bozkaplan Ş.A. (2009), Aksan Y. (2012). In their works they provide full definitions of the concept "euphemism" and distinguish its distinctive features. In addition, such linguists as Adler D. (1994), Gumanova Yu.L. (2000), Ter-Minasova S.G. (2000), Palazhchenko M.Yu. (2004), Panin V.V. (2004), Vildanova G.A. (2008), Halmari H. (2010), Crespo-Fernandez E. (2014), Bozkaplan Ş.A. (2009), Aksan Y. (2012) gave the detailed description of political correctness and offered the most appropriate classification of politically correct euphemisms, which provided the basis for our research. This classification allowed us to carry out the comparative analysis of politically correct euphemisms used in American and Turkish online periodicals of the beginning of the $21^{\text {st }}$ century. Based on the analysis we determined the most common types of politically correct euphemisms in the language of modern American and Turkish mass media and established the reasons for their frequent use.

\section{Conclusions}

The analysis demonstrates the wide use of politically correct lexemes in the language of American and Turkish online periodicals of the beginning of the $21^{\text {st }}$ century (2000-2015). The debatable issues of interethnic relations and international conflicts, the social status of the financially disadvantaged and vulnerable population (people with mental and physical disabilities, low-income citizens and elderly people) receive a broad coverage in American and Turkish online newspapers and magazines. Euphemisms are widely employed while describing, mitigating and masking the negative associations related to the mentioned issues in mass media that indicates the functioning of euphemisms in the language of mass media within the framework of political correctness. It 
should be noted that compared to the American mass media, which is characterized by a great choice of politically correct euphemisms, the Turkish periodicals contain a small percentage of politically correct lexemes. In the Turkish language the theory of political correctness has the greatest impact on the formation of politically correct euphemisms in relation with the fight against the discrimination of mentally and physically handicapped people, various forms of aggression including military aggression. Moreover, in the Turkish language we distinguish one more group of politically correct lexemes which is not widely used in the American mass media, that is, phraseological euphemisms.

\section{Acknowledgments}

The work is performed according to the Russian Government Program of Competitive Growth of Kazan Federal University.

\section{References}

Adler, D. (1994). Bor'ba protiv politicheskoy korrektnosti. Amerika, 442, 5-11.

Ağzı ile kuş tutsa Baykal'a artık oy yok. (2004, May 26). In Vatan Gazetesi. Retrieved April 30, 2015, from http://www.gazetevatan.com/-agzi-ile-kus-tutsa-baykal-a-artik-oy-yok--28574-gundem/

Aksan, Y. et al. (2012). Construction of the Turkish National Corpus (TNC). Proceedings of the Eighth International Conference on Language Recources and Evaluation (LREC, 2012). Istanbul, Turkey. Retrieved April 30, 2015, from http://www.lrec-conf.org/proceedings/lrec2012/pdf/991_Paper.pdf

Blum, J. (2003, April 9). D.C. Strikes Deal With Special-Ed Schools; Fees for Private Programs Are Cut in Exchange for Enrollment Guarantees. In The Washington Post. Retrieved April 28, 2015, from http://www.highbeam.com/doc/1P2-255009.html

Bozkaplan, Ş. A. (2009). Anadolu Ağızlarında Güzel Adlandırma Örnekleri. International Periodical for the Languages, Literature and History of Turkish or Turkic, 4/3.

Burridge, K. (1999, March 20). Is Political Correctness a Euphemism for Euphemism? Retrieved April 29, 2015, from http://www.abc.net.au/radionational/programs/linguafranca/is-political-correctness-a-euphemism -for-euphemism/3567154\#transcript

Crespo-Fernandez, E. (2014). Euphemism and political discourse in the British regional press. Brno Studies in English, 40(1), 5-26. http://dx.doi.org/10.5817/BSE2014-1-1

DeFord, S. (2003, July 24). Living With Limits, Building Businesses; Disabled Get Help in Shaping Self-Employment Plans. In The Washington Post. Retrieved April 28, 2015, from http://www.highbeam.com/doc/1P2-278075.html

Engelli kıza tecavüze 18 y1l. (2015, April 30). In Milliyet. Retrieved April 30, 2015, from http://www.milliyet.com.tr/engelli-kiza-tecavuze-18-yil-gundem-2052301/

Ersan, Y. (2005). Siyasal İletişimde "Güzel Adlandırma" kullanımı. IV. Dil, Yazın ve Deyiş̧ilim Sempozyumu Bildirileri. Çanakkale. 63-84.

Fears, D. (2003, July 14). Race divides Hispanics, reports say. In The Washington Post. Retrieved April 28, 2015, from http://mumford.albany.edu/census/othersay/071403 WashingtonPost.pdf

Görme engelli anne, bebeğini bu gözlükle gördü. (2015, January 26). In Hürriyet. Retrieved April 30, 2015, from http://www.hurriyet.com.tr/teknoloji/28051748.asp

Gumanova, Yu. L. (2000). Politicheskaia korrektnost': kak eto delayetsia v Rossii. Possiia i Zapad: dialog kul'tur, vypusk 8, t.1, 195-202.

Halanskaya, A. A. (2006). Lingvistika tekstov politicheskih novostey v aspekte kommutikativtyh i manipuliativnyh strategiy: Na materiale pechatnyh izdaniy kachestvennoy rossiyskoy i britanskoy pressy 2000-2005gg. Avtoreferat kandidatskoy dissertatsii. Krasnodar.

Halmari, H. (2010). Political Correctness, euphemism, and language change: the case of "people first". Journal of Pragmatics, 43(3), 828-840. http://dx.doi.org/10.1016/j.pragma.2010.09.016

Harvard black guide will delete offending pages. (2003, February 7). In The New York Times. Retrieved April 28, 2015, from http://www.nytimes.com/2003/02/07/us/harvard-black-guide-will-delete-offending-pages. html

Jonsson, P. (2013, November 23). Brooklyn attack arrest: Is "knockout game" a hate crime? In Christian Science Monitor.

Retrieved

April

28 ,

2015,

from 
http://www.csmonitor.com/USA/Justice/2013/1123/Brooklyn-attack-arrest-Is-knockout-game-a-hate-crimevideo

Katsev, A. M. (1998). Iazykovoye tabu i evfemiia. Sankt-Peterburg.

Kiprskaia, Ye. V. (2005). Politicheskiie evfemizmy kak sredstvo kamuflirovaniia deystvitol'nosti v SMI (na primere konflikta v Irake 2003-2004gg.). Avtoreferat kandidatskoy dissertatsii. Izhevsk.

Komlev, N. G. (1999). Slovar' inostrannyh slov. Moskva: Eksmo-press.

Leontovich, O. A., \& Sheygal, Ye. I. (1998). Zhizn'i kul'tura SShA. Volgograd: Stanitsa 2.

Moskvin, V. P. (2001). Evfemizmy: sistemniye sviazi, funktsii i sposoby obrazovaniia. Voprosy iazykoznaniia, 3, 58-70.

Muhamedianova, G. N. (2005). Evfemiia v obschestvenno-politicheskoy leksike (na materiale sovremennogo nemetskogo, russkogo i bashkirskogo iazykov). Avtoreferat kandidatskoy dissertatsii. Ufa.

Mui Q. Ylan. (2003, October 30). Students say gap deeper that scores; Blacks tell panel they feel left out. In The Washington Post. Retrieved April 28, 2015, from http://www.highbeam.com/doc/1P2-123172.html

Mulrine, A. (2013, December 5). Chemical weapons: How Pentagon plans to destroy Syria's stockpile at sea. In Christian Science Monitor. Retrieved April 28, 2015, from http://www.csmonitor.com/World/Security-Watch/2013/1205/Chemical-weapons-How-Pentagon-plans-todestroy-Syria-s-stockpile-at-sea

Neaman, J. S., \& Silver, C. G. (1995). Book of Euphemism. The hilarious guide to the unmentionable. London: Wordsworth Editions LTD.

Palazhchenko, M. Yu. (2004). Politicheskaia korrektnost'v yazykovoi i kul'turnoi traditsii (na angliyskom $i$ russkom materiale). Avtoreferat kandidatskoy dissertatsii. Moskva.

Panin, V. V. (2004). Politicheskaia korrektnost' kak kul'turno-povedencheskaia i yazykovaia kategoriia. Avtoreferat kandidatskoy dissertatsii. Tyumen'.

Perraino, K. (2000, September 17). Berkley's new colors. In Newsweek. Retrieved April 30, 2015, from http://www.newsweek.com/berkeleys-new-colors-159633

Ter-Minasova, S. G. (2000). Yazyk i mezhkul'turnaia kommunikatsiia. Moskva: Slovo.

Vanderpool, T. (2004, January 6). Why more senior citizens are carrying guns? In Christian Science Monitor. Retrieved April 28, 2015, from http://www.csmonitor.com/ 2004/0106/p02s01-ussc.html

Vildanova, G. A. (2008). Gendernyi aspekt evfemizatsii (na materiale angliyskogo iazyka). Avtoreferat kandidatskoy dissertatsii. Birsk.

Wood, B. D. (2013, December 6). Jennifer Epps inspires inner-city students and teachers in Los Angeles to excel. In Christian Science Monitor. Retrieved April 28, 2015, from http://www.csmonitor.com/World/Making-a-difference/2013/1206/Jennifer-Epps-inspires-inner-city-studen ts-and-teachers-in-Los-Angeles-to-excel

Yaşlı, F. (2015, April 30). Charlie Hebdo: Orada terörist, burada özgürlük savaş̧̧ısı. In Yurt Gazetesi. Retrieved April 30, 2015, from http://www.yurtgazetesi.com.tr/kose-yazilari/charlie-hebdo-orada-terorist-burada-ozgurluk-savascisi-h9715. html

Zeyrik, D. (2015, Şubat 24), “Özgürlük savaşçısı” ne demek? In Hürriyet. Retrieved April 30, 2015, from http://www.hurriyet.com.tr/gundem/25877930.asp

\section{Copyrights}

Copyright for this article is retained by the author(s), with first publication rights granted to the journal.

This is an open-access article distributed under the terms and conditions of the Creative Commons Attribution license (http://creativecommons.org/licenses/by/3.0/). 